\title{
Erratum to: The Thermodynamics and Kinetics of High-Entropy Alloys
}

Published online: 22 August 2017

(C) ASM International 2017

Erratum to: J. Phase Equilib. Diffus. (2017)

\section{8:351-352}

DOI 10.1007/s11669-017-0584-1

The August issue of JPED Vol. 38 contained an error in its Editorial, "The Thermodynamics and Kinetics of HighEntropy Alloys." The wrong name was given for the primary author of the paper entitled "TCHEA1: A Thermodynamic Database Not Limited for 'High Entropy' Alloys." The correct author's name is Dr. Huahai Mao. We apologize to Dr. Mao and anyone else affected by this error.

\section{M.C. Gao}

National Energy Technology Laboratory/AECOM, OR, email: Michael.Gao@netl.doe.gov

\section{J.-C. Zhao}

Associate Editor

Journal of Phase Equilibria and Diffusion

The Ohio State University Columbus, $\mathrm{OH}$, email: zhao.199@osu.edu

\section{J.E. Morral}

Editor-in-Chief

Journal of Phase Equilibria and Diffusion The Ohio State University, Columbus, $\mathrm{OH}$, email: jemorral@gmail.com 